\title{
Tree species diversity around some Mayas in Dinder National Park, Sudan
}

\author{
Tahani A. Hassan \\ Department of wildlife sciences, College of Natural Resources and Environmental Studies, University of Bahri, Sudan. \\ Email: tahanihassanm@gmail.com. \\ Copyright () 2017 Hassan. This article remains permanently open access under the terms of the Creative Commons Attribution License 4.0, which \\ permits unrestricted use, distribution, and reproduction in any medium, provided the original work is properly cited.
}

Received 13th February, 2017; Accepted 11th March, 2017

\begin{abstract}
This study was conducted in Dinder National Park, during the dry season from February to May 2016, with the aim to determine the density, relative density, frequency and abundance of trees in the five Mayas in Dinder National Park. Data was collected using the transect line sampling method in the five Mayas namely; Abdel Ghani, Musa, RasAmir, Ein- Elshamis and Gererrisa. Abundance of trees and densities per Kilometer ${ }^{2}$ varied but highest abundance trees were Acacia seyal, Ziziphus spp, Combertum, Balanitie aegyptiaca and Acacia polycantha. Acacia seyal covers larger area in Dinder National Park and also one of the common and dominant tree species. So control of the spread of this species could be by cutting and selling them at local markets and nearby villages to avoid the entrance of people to the park for that purpose.
\end{abstract}

Key words: Transect line, densities, relative density, frequency, abundance.

\section{INTRODUCTION}

The vegetation is sparse in the desert zones of the Sudan and various species of Acacia occur in the regions near the Nile valleys. Large forested areas are found in the central Sudan, especially in the river valleys. Among the most common trees are (hashab) Acacia Senegal, (talih) - Acacia seyal, (heglig) - Balanite aegyptiaca and several species of Acacia mellifera. Other varieties of timber trees are found in White Nile basin (Kanno, 2004). The vegetation which includes forest and pastures is the most important element in Dinder National Park (Kanno, 2004). Without vegetation almost no life exists in the park. It is the main source of food for almost all wildlife species of the park and it prevents soil erosion. Vegetation decomposition increases soil fertility and compaction. Therefore, any deterioration in the vegetation means instability in the park ecosystem (Kanno, 2004). Acacia seyal, Combertum hartmnnianum and Balanite aegyptiaca formed the woodland with tall grass including sorghum species. The reverie forest is characterized by Hyphaena thebacia, Acacia seibriana,Tamarindus indica and dalbergiame lanoxylon. Harrison and Jackson (1958) gave a general classification of Sudan vegetation in which Dinder area is included in the Acacia seyal - Balanite savanna alternating with grass area zone, and Anogeissus combretum hartmannianum savanna woodland zone. The description given by Desman (1972) differs from the rest, in that Desman has classified the vegetation of Dinder National
Park into four categories, wooded grassland, open grassland, wooded land and riverine forest. Hakim et al. (1978) and Abdel Hameed (1983) recognized three types of ecosystem Acacia seyal - Balanites woodland, riverine ecosystem and the mayas (wetland ecosystem). Dinder is mainly and extensively made of savanna grassland, woodland and rain river forest with and a few hills and high land located along and near the Ethiopian border. The park has all the three ecosystems, each with its own plant and animal communities.

Dinner National Park is large area with high diversity of topographic, ecological zones which make the ground survey so difficult to cover the whole park. The vegetation cover in the Park is characteristically important because it relates to the wildlife management which provides the animals with food, water, shelter and cover. The aim of this study was to identify the trees species and their distribution, densities, relative densities, frequency and abundance in the park.

\section{MATERIALS AND METHODS}

\section{Study area}

Dinder National Park was established in 1935. It is the 
Table 1.Densities, relative densities, frequency and abundance of trees in north and west direction of Abdel Ghani Maya in Dinder National Park.

\begin{tabular}{|c|c|c|c|c|c|c|c|c|c|c|}
\hline \multirow{3}{*}{ Tree species } & \multicolumn{10}{|c|}{ Transects } \\
\hline & \multicolumn{5}{|c|}{ North } & \multicolumn{5}{|c|}{ West } \\
\hline & $\begin{array}{l}\text { No of } \\
\text { Trees }\end{array}$ & $\begin{array}{c}\text { Density per } \\
\text { km }\end{array}$ & $\begin{array}{l}\text { Relative } \\
\text { density }\end{array}$ & Frequency & Abundance & $\begin{array}{l}\text { No of } \\
\text { Trees }\end{array}$ & $\begin{array}{l}\text { Density } \\
\text { per } \mathbf{k m}\end{array}$ & $\begin{array}{l}\text { Relative } \\
\text { density }\end{array}$ & Frequency & Abundance \\
\hline Acacia Seyal & 46 & 7324.8 & 0.0722 & 0.65 & 7324.8 & 32 & 5095.5 & 0.03129 & 0.5 & 5095.5 \\
\hline Acacia nilotica & 69 & 10987.2 & 0.108 & 0.15 & 10987.2 & 18 & 2866.2 & 0.0176 & 0.1 & 2866.2 \\
\hline Acacia Polycantha & 123 & 19585.1 & 0.094 & 0.6 & 19585.1 & 425 & 67675.1 & 0.4157 & 0.7 & 67675 \\
\hline Acacia Sieberiana & 0 & 0 & 0 & 0 & 0 & 0 & 0 & 0 & 0 & 0 \\
\hline Balaniteaeygtiaca & 38 & 6050.1 & 0.0596 & 0.6 & 6050.1 & 53 & 8439.4 & 0.0518 & 0.6 & 8439.4 \\
\hline ZizphusSpp & 0 & 0 & 0 & 0 & 0 & 13 & 2070.0 & 0.0127 & 0.1 & 2070.0 \\
\hline CombertumSpp & 18 & 159.2 & 1.569 & 0.05 & 159.2 & 5 & 0 & 0 & 0 & 0 \\
\hline Cratevaadansonia & 1 & 2866.2 & 0.028 & 0.4 & 2866.2 & 0 & 796.1 & 4.890 & 0.1 & \\
\hline Gardinaspp & 0 & 0 & 0 & 0 & 0 & 0 & 0 & 0 & 0 & 0 \\
\hline Total & 295 & 101432.6 & & & & 546 & 162796.9 & & & \\
\hline
\end{tabular}

most important Wildlife reserve in southeast Sudan. The park is located in the north eastern Blue Nile state towards the Ethiopian border between latitudes $\left(11\right.$ to $\left.13^{\circ} \mathrm{N}\right)$ and longitudes $(35$ to $\left.13^{\circ} \mathrm{E}\right)$ and about $550 \mathrm{~km}$ south east Khartoum. It situated between two seasonal rivers Dinder and Rahad. Dinder National Park covers about $\left(100,446.8 \mathrm{Km}^{2}\right)$. The climatic conditions of the park in general can be summarized as cool and dry in winter and wet and warm in summer (Hashim, 1987).

\section{Methods}

The study was conducted in Dinder National Park during the dry season from February to May 2016. The vegetation data were collected along two randomly placed (in different directions) $1 \mathrm{~km}$ long transects at each of the five Mayas.

The starting point of transects was taken from the edge of the Maya along to the woodland. Along each transect a circular plots of each 10 meters radius were established (totaling to 20 plots) and the tree species inside the circle were identified, counted and recorded in all the 20 plots. The area of each plot was calculated according to the formula $A=\pi r^{2}$ then multiplied by 20 to deter-mine the total area surveyed along the transect $(1 \mathrm{~km})$.

The summation individual number of stems of each tree species was computed. Then, the density, the relative density, frequency, and abundance of each tree species were calculated.

The data was calculated according to formula:

Density $=\frac{\text { Total number of individual }}{\text { Area sampled }}$

Relative density $=\frac{\text { Density of a given species }}{\text { Total density of all species }} \times 100$

Frequency $=\frac{\text { Number of plots species occur }}{\text { Total number of plots }} \times 100$

Abundance $=\frac{\text { Number of individuals }}{\text { Number of plots in which species occur }}$

\section{RESULTS AND DISCUSSION}

The dominant tree species in Abdel Ghani Maya was Acacia polycantha, with density of (19585.1) per $\mathrm{km}^{2}$ followed by Acacia nilotica (10987.2), Balanities aegyptiaca (6050.1) Acacia seyal (7324.8) and Combertum spp (2866.2). Zizyphus spinachristi and gardenia spp were not observed. Acacia seyal showed the highest densities along the transect laid out in northern direction than the one in western direction and this may be attributed to the availability of baboon (Papio anubis) in that area who contributed significantly in distribution of these trees. Acacia nilotica showed higher density in northern direction and this may be attributed to the availability of water in that area (Table 1).

The number of tree species were higher in western direction than in north of the Musa Maya. The dominant trees species were Acacia seyal with the density of 99044.5 per $\mathrm{km}^{2}$ followed by Zizphus spp, Acacia nilotica, Balanit eaegyptiaca and Combertum spp (Table 2). 
Table 2. Densities, relative density, frequency, and abundance of trees in north and west direction of Musa Maya in Dinder National Park.

\begin{tabular}{|c|c|c|c|c|c|c|c|c|c|c|}
\hline \multirow{3}{*}{ Tree species } & \multicolumn{10}{|c|}{ Transects } \\
\hline & \multicolumn{5}{|c|}{ North } & \multicolumn{5}{|c|}{ West } \\
\hline & $\begin{array}{l}\text { No of } \\
\text { Trees }\end{array}$ & $\begin{array}{l}\text { Density } \\
\text { per km }\end{array}$ & $\begin{array}{l}\text { Relative } \\
\text { density }\end{array}$ & Frequency & Abundance & $\begin{array}{l}\text { No of } \\
\text { Trees }\end{array}$ & $\begin{array}{l}\text { Density } \\
\text { per km }\end{array}$ & $\begin{array}{l}\text { Relative } \\
\text { density }\end{array}$ & Frequency & Abundance \\
\hline Acacia Seyal & 90 & 14331.2 & 0.3405 & 0.7 & 14331.2 & 622 & 99044.5 & 0.78182 & 1.8 & 99044.5 \\
\hline Acacia nilotica & 56 & 8917.1 & 0.2119 & 0.2 & 8917.1 & 3 & 477.7 & 3.7708 & 0.1 & 477.7 \\
\hline Acacia Polycantha & 8 & 1315.8 & 0.0312 & 0.1 & 1315.8 & 2 & 318.4 & 2.5133 & 0.1 & 318.4 \\
\hline Acacia Sieberiana & 2 & 318.4 & 7.566 & 0.05 & 318.4 & 2 & 318.4 & 2.5133 & 0.1 & 318.4 \\
\hline Balaniteaeygtiaca & 19 & 3025.4 & 0.0718 & 0.5 & 3025.4 & 7 & 1114.7 & 8.7990 & 0.15 & 1114.7 \\
\hline ZizphusSpp & 68 & 1082.0 & 0.2573 & 0.35 & 1082.0 & 108 & 17197.4 & 0.1347 & 0.5 & 17197.4 \\
\hline CombertumSpp & 12 & 1433.1 & 0.0340 & 0.1 & 1433.1 & 9 & 6461 & 0.0510 & 0.05 & 6461 \\
\hline Cratevaadansonia & 9 & 1910.9 & 0.0454 & 0.35 & 1910.9 & 4 & 1433.1 & 0.0113 & 0.2 & 1433.1 \\
\hline Gardinaspp & 0 & 0 & 0 & 0 & 0 & 2 & 318.4 & 2.5133 & 0.2 & 318.4 \\
\hline Total & 264 & 42079.9 & & & & 759 & 126683.6 & & & \\
\hline
\end{tabular}

Table 3. Densities, relative densities, frequency and abundance of trees in north and west direction of Ras Amir Maya in Dinder National Park.

\begin{tabular}{|c|c|c|c|c|c|c|c|c|c|c|}
\hline \multirow{3}{*}{ Tree species } & \multicolumn{10}{|c|}{ Transects } \\
\hline & \multicolumn{5}{|c|}{ North } & \multicolumn{5}{|c|}{ West } \\
\hline & $\begin{array}{l}\text { No of } \\
\text { Trees }\end{array}$ & $\begin{array}{l}\text { Density } \\
\text { per km }\end{array}$ & $\begin{array}{l}\text { Relative } \\
\text { density }\end{array}$ & Frequency & Abundance & $\begin{array}{l}\text { No of } \\
\text { Trees }\end{array}$ & $\begin{array}{l}\text { Density } \\
\text { per km }\end{array}$ & $\begin{array}{l}\text { Relative } \\
\text { density }\end{array}$ & Frequency & Abundance \\
\hline Acacia Seyal & 138 & 21974.5 & 0.6301 & 0.9 & 21974.5 & 32 & 5095.5 & 0.2580 & 0.25 & 5095.5 \\
\hline Acacia nilotica & 0 & 0 & 0 & 0 & 0 & 15 & 2388.5 & 0.1209 & 0.15 & 2388.5 \\
\hline Acacia Polycantha & 12 & 1910.9 & 0.05479 & 0.15 & 1910.9 & 2 & 318.4 & 0.01612 & $0.1 \mathrm{~s}$ & 318.4 \\
\hline Acacia Sieberiana & 0 & 0 & 0 & 0 & 0 & 5 & 796.1 & 0.0403 & 0.15 & 796.17 \\
\hline Balaniteaeygtiaca & 16 & 2547.8 & 0.07305 & 0.4 & 2547.8 & 22 & 3503.1 & 0.1774 & 0.5 & 3503.1 \\
\hline ZizphusSpp & 8 & 1273.9 & 0.03652 & 0.15 & 1273.9 & 47 & 7484.0 & 0.3790 & 0.4 & 7484.07 \\
\hline CombertumSpp & 20 & 3980.9 & 0.1141 & 0.1 & 3980.9 & 0 & 159.2 & 0.0628 & 0.05 & 159.2 \\
\hline Cratevaadansonia & 25 & 3184.8 & 0.0913 & 0.35 & 3184.8 & 1 & 0 & 0 & 0 & 0 \\
\hline Gardinaspp & 0 & 0 & 0 & 0 & 0 & 0 & 0 & 0 & 0 & 0 \\
\hline Total & 264 & 34872.8 & & & & 124 & 19744.8 & & & \\
\hline
\end{tabular}

In Ras- Amir Maya the dominant tree species are Acacia seyal with the density of 21974.5 per $\mathrm{km}^{2}$ followed by Zizphus spp, Crateva adonensonia, Balanitie aegyptiaca and
Combertum spp. In general we found that the densities of tree species in northern direction is greater than that in the western direction and this may be attributed to the dryness of that part
(Table 3).

In southern side of Ein- Elshmis Maya the number of tree species in the south is greater than that of the northern one. The dominant tree species 
Table 4. Densities, relative densities, frequency and abundance of trees in north and south direction of Ein- Elshamis Maya in Dinder National Park.

\begin{tabular}{|c|c|c|c|c|c|c|c|c|c|c|}
\hline \multirow{3}{*}{ Tree species } & \multicolumn{10}{|c|}{ Transects } \\
\hline & \multicolumn{5}{|c|}{ North } & \multicolumn{5}{|c|}{ South } \\
\hline & $\begin{array}{l}\text { No of } \\
\text { Trees }\end{array}$ & $\begin{array}{l}\text { Density } \\
\text { per km }\end{array}$ & $\begin{array}{l}\text { Relative } \\
\text { density }\end{array}$ & Frequency & Abundance & $\begin{array}{l}\text { No of } \\
\text { Trees }\end{array}$ & $\begin{array}{l}\text { Density } \\
\text { per km }\end{array}$ & $\begin{array}{l}\text { Relative } \\
\text { density }\end{array}$ & Frequency & Abundance \\
\hline Acacia Seyal & 150 & 23885.3 & 0.5136 & 0.85 & 23885.3 & 45 & 212 & 33757.9 & 0.670 & 1 \\
\hline Acacia nilotica & 0 & 0 & 0 & 0 & 0 & 0 & 0 & 0 & 0 & 0 \\
\hline Acacia Polycantha & 63 & 10031.8 & 0.2157 & 0.85 & 10031.8 & 20 & 15 & 2388.5 & 0.047 & 0.25 \\
\hline Acacia Sieberiana & 0 & 0 & 0 & 0 & 0 & 0 & 0 & 0 & 0 & 0 \\
\hline Balaniteaeygtiaca & 2 & 318.4 & 6.847 & 0.1 & 318.4 & 86 & 58 & 9235.6 & 0.183 & 0.6 \\
\hline ZizphusSpp & 3 & 477.7 & 0.0102 & 0.5 & 477.7 & 27 & 72 & 11464.9 & 0.227 & 0.4 \\
\hline CombertumSpp & 74 & 0 & 0 & 0 & 0 & 42 & 0 & 0 & 0 & 0 \\
\hline Cratevaadansonia & 0 & 11783.4 & 0.253 & 0.8 & 11783.4 & 0 & 24 & 3821.6 & 0.075 & 0.55 \\
\hline Gardinaspp & 0 & 0 & 0 & 0 & 0 & 0 & 0 & 0 & 0 & 0 \\
\hline Total & 292 & 46496.6 & & & & 220 & 381 & & & \\
\hline
\end{tabular}

Table 5. Densities, relative densities, frequency and abundance of trees in northern and southern direction of Grerrisa Maya in Dinder National Park.

\begin{tabular}{|c|c|c|c|c|c|c|c|c|c|c|}
\hline \multirow{3}{*}{ Tree species } & \multicolumn{10}{|c|}{ Transects } \\
\hline & \multicolumn{5}{|c|}{ South } & \multicolumn{5}{|c|}{ West } \\
\hline & $\begin{array}{l}\text { No of } \\
\text { Trees }\end{array}$ & $\begin{array}{l}\text { Density } \\
\text { per km }\end{array}$ & $\begin{array}{l}\text { Relative } \\
\text { density }\end{array}$ & Frequency & Abundance & $\begin{array}{l}\text { No of } \\
\text { Trees }\end{array}$ & $\begin{array}{l}\text { Density } \\
\text { per km }\end{array}$ & $\begin{array}{c}\text { Relative } \\
\text { density }\end{array}$ & Frequency & Abundance \\
\hline Acacia Seyal & 57 & 9076.4 & 0.2896 & 0.75 & 9076.4 & 85 & 13535.0 & 0.338 & 0.75 & 13535.0 \\
\hline Acacia nilotica & 2 & 318.4 & 0.0101 & 0.1 & 318.4 & 10 & 1592.3 & 0.0398 & 0.05 & 1592.3 \\
\hline Acacia Polycantha & 45 & 7165.6 & 0.2286 & & 7165.6 & 2 & 318.4 & 7.966 & 0.1 & 318.4 \\
\hline Acacia Sieberiana & 1 & 129.2 & 4.1226 & 0.05 & 129.2 & 0 & 0 & 0 & 0 & 0 \\
\hline Balaniteaeygtiaca & 7 & 1114.7 & 0.0355 & 0.15 & 1114.7 & 20 & 3184.8 & 0.0796 & 0.05 & 3184.8 \\
\hline ZizphusSpp & 9 & 1433.1 & 0.0457 & 0.15 & 1433.1 & 101 & 16082.8 & 0.402 & 0.35 & 16082.8 \\
\hline CombertumSpp & 61 & 2070.0 & 0.0660 & 0.15 & 2070.0 & 32 & 0 & 0 & 0 & 0 \\
\hline Cratevaadansonia & 13 & 9713.3 & 0.3099 & 0.76 & 9713.3 & 0 & 5095.5 & 0.127 & 0.5 & 5095.5 \\
\hline Gardinaspp & 2 & 318.4 & 0.0101 & 0.1 & 318.4 & 1 & 159.2 & 25350.3 & 0.05 & 159.2 \\
\hline Total & 197 & 31339.1 & & & & 251 & 39968 & & & \\
\hline
\end{tabular}

in Ein -Elshamis Maya were Acacia seyal with the density of 33757.9 per $\mathrm{km}^{2}$ followed by Combertumspp, Zizphuaspp, Acacia polycantha and Balanite aegyptiaca (Table 4).
Gardenia spp showed fewer densities in Gererrisa Maya and the number of trees in western direction is higher than the southern one. The dominant tree species in Gererrisa Maya were Zizphus spp with the density of 16082.8 per $\mathrm{km}^{2}$ followed by Acacia seyal, Acacia polycantha, Combertum spp and Balanite aegyptiaca (Table 5).

The general dominant tree species was Acacia 
seyal in all area searched and this is in line with the findings of (Desman, 1972). Acacia seyal and Balanite aegytiaca association changes into Anogeissus leiocarous and Combretum spp (Hakim and Nimir, 1983).

The recent study revealed that in burnt areas almost $90 \%$ of the regenerated growth is of Acacia seyal which is more resistant to fire than the other two dominant species, Balanite aegyptiaca and Combretum hartmannianum and this agreed with the findings of Abdel Hameed et al (1999)

Form the above discussion ,the expansion of these dominant tree species at the account of open grass land has a negative impact on wildlife species that prefer open grass land as their hahitat.

\section{Conclusion}

The densities of the tree species in the five Mayas are different. The highest densities were observed in Abdel Ghani Maya followed by Musa, Ein-Elshamis, Ras-Amir and Gererrisa. Acaia seyal showed the highest densities in comparison with other tree species. Acacia seyal covers larger area in Dinder National Park and also one of the common and dominant tree species.

\section{Recommendation}

i. Control the spread of Acacia seyal could be by cutting and selling them at local markets and nearby villages to avoid the entrance of people to the park for that purpose.

ii. Establishment of fire lines to control the annual fires incident.

iii. Mayas should be excavated to avoid their phasing out and to increase their water holding capacity.

\section{CONFLICT OF INTEREST}

The author declares that there is no conflict of interest.

\section{REFERENCES}

Abdel Hameed, S. M. (1983). Vegetation of Mayas in Dinder National Park, Sudan. Msc. Thesis, Colorado State University U.S.A. 93p.

Abdel Hameed, S. M. (1999). Biosphere Reserves in Sudan. Between Theory and Implementation, the fourth scientific conferences National centre for Research, April, 6-8, 1999.

Desman, (1972). Development and management of the Dinder National Park and its wildlife, Rome. p.61. Hakim, S., Fadlalla, B., Awad, N. M., \& Wahab, S. A. (1978). Ecosystem of the vegetation of Dinder National Park. Report Wildlife Research Center, Khartoum, Sudan, 9p.

Hakim, S. A., \& Nimir, M. B. (1983). Fire as an environmental factor WRC, (unpublished paper). 7p.

Harrison, M. N., \& Jackson, J. K. (1958), Ecological classification of the vegetation of the Sudan.

Hashim, I. M. (1987). Relationship between biomass of forage used and masses of fecal pallets of Wildlife animal, in meadows of Dinder National Park. Agric. J. Ecology, 25, 277223.

Kanno, O. I. (2004). Application of Remote Sensing in Monitoring Ecological Changes in Dinder National Park, Sudan. 